$\mathbb{T}$ periodica polytechnica

\author{
Social and Management Sciences \\ $14 / 2$ (2006) 53-69 \\ doi: 10.3311/pp.so.2006-2.02 \\ web: http://www.pp.bme.hu/so \\ (c) Periodica Polytechnica 2006 \\ RESEARCH ARTICLE \\ Imami Drini / Lami Endrit \\ Received 2007-09-14
}

\section{Searching for political business cycle in Albania}

\begin{abstract}
In our search for Political Business Cycles in Albania, we found clear evidence of the attempts made by the incumbent to manipulate the economy. There is a statistically significant increase of public expenditures before elections aiming at reducing unemployment and increasing output, in order to please the voters.

Regarding the macroeconomic outputs, we have found, evidence of PBC in GDP and unemployment but not in inflation. The fiscal expansionary policy before elections, leads to higher GDP and lower unemployment before/during elections. However, the inflation does not significantly increase as expected. That might be attributed to the mature monetary policy conducted by the Central Bank which enjoys a relatively high level of independence.
\end{abstract}

\section{Keywords \\ political busibness cycles $\cdot$ Albania}

\section{Acknowledgement}

We are thankful to Professors Dietmar Meyer, Ann-Margret Westin, Holger Kächelein and H. Dieter Wenzel, as well as to $D A A D$ for the precious support that enabled our research.

\section{Imami Drini}

Department of Agriculture Economics Agriculture University of Tirana Universiteti Bujqesor i Tiranes, Koder-Kamez, Tirane, Albania e-mail: drinimami@yahoo.com

\section{Lami Endrit}

Makroeconomics Department, Ministry of Finance of the Republic of Albania, Bul. Deshmoret e Kombit, Tirane, Albania

e-mail: elami@minfin.gov.al

\section{Introduction}

No previous research for Political Business Cycle (PBC) has been done before on Albania, to best of our knowledge. However, it is widely believed in Albania as elsewhere, that the governments may use all the means they possess, including economic policy instruments, to enhance the chances of reelections. The government may engage in expansionary economic policies prior elections, increasing output and decreasing unemployment, in order to please the voters, creating this way Political Business Cycles.

The objective of our work is to search for the existence of $\mathrm{PBC}$ in Albania. The testing for PBC is done by investigating and analysing the economic policy instruments and macroeconomic outcomes. We will statistically test for PBC in fiscal and monetary instruments, as well as in the related main economic outcomes; unemployment, output and inflation. We assume that the government may follow expansionary fiscal and monetary policy, to reduce unemployment and increase output before/during elections, and as a result of this expansionary economic policy, the inflation may increase during/after elections.

We will analyse data for the variables mentioned above at monthly or quarterly level, between January, 1998 and March, 2007. The period prior 1998 was not taken into consideration because of the lack of reliable data and because the economic, political and institutional framework followed a chaotic and abnormal pattern between early 1990' and 1997 and including the extreme year of 1997, might affect the nature of time series analyses. During the analysed period there took place two parliamentary elections and three local elections. The local elections were considered important also because they were seen as a test for the political forces and as a referendum for the central government.

It is essential to investigate both, policy instruments and macroeconomic indicators, because it may be possible that there may be obvious attempts by the incumbent to manipulate economy by (statistically) significantly altering fiscal and monetary variables, but without succeeding to significantly affect the (intended and unintended) macroeconomic variables (i.e. inflation, output and unemployment) for what ever reasons. On the other 
hand, Business Cycles may occur and coincide in election timing, however not caused by instrument policies, but by other factors, such as preferences and expectations [19](Suzuki, 1992). Therefore, there may be other cyclical phenomena that may offset the effect of the policy instruments on economic outcomes. In this context, it is important in our analyses to investigate and compare the (possible) PBC cycles in policy instruments with policy cycles in macroeconomic outcomes.

\section{Social, Economic and Political Background of Alba- nia}

In this section, we will give an overview of Albania's social, political and economic structure, characteristics and trends (data from Albanian Institute of Statistics, INSTAT) ${ }^{1}$.

Before the Second World War, Albania was an undeveloped, largely rural based society and after the war, it became part of the communist block. The country embraced democracy and market economy in the early 1990s. Despite of economic reform, Albania still remains one of the poorest countries in Europe, and that is to a large extent a result of the past communist rule which left the country in a deplorable state. The economic and political communist version applied in Albania was one of the toughest in the Eastern Block. All private enterprises were shut down and nationalized and all private initiative was banned out of economic life, prices and the investments were decided by the authorities. The economic situation in the early $1990 \mathrm{~s}$ was in the state of a collapse. The overall infrastructure and industries, in general, was old and inefficient. Despite efforts by the communist regime to industrialize the country, Albania had still remained in large a rural based society, with about $2 / 3$ of the population living and working in villages.

In the early 1990s, Albania underwent the social, economic and political changes, like the rest of the former communist block. The initial years were characterized by high inflation, reduced output and an increasing budget deficit. Policymakers implemented the reforms in a fast and radical way ('shock therapy') aiming at deregulation, decentralization and liberalization in order to transfer the power of resource allocation to the emerging markets. In the following years, the economy and Albanian Lek stabilized, and led by the agricultural sector, real GDP grew. The speed of private entrepreneurial response to Albania's opening and liberalizing was better than expected but the collapse of the infamous pyramid schemes in 1997 and the economic, political and social instability that followed were a tremendous setback, from which Albania's economy still continues to recover.

However, the cumulative growth since 1990 is among the highest of all transition economies. That is the reason why Albania's real income has recovered to pre-transition levels, with an estimated GNI per capita of about US\$2,510 in 2005. Real GDP has grown by more than $7 \%$ per year between 1994 and 2001

\footnotetext{
1 www.instat.gov.al
}

(except for the 1997) and by about 5,4\% per year between 2002 and 2005 whereas the inflation has been relatively low, with an average of about $2.5 \%$ per year between 2004-2006. The public debt reached $57.5 \%$ of GDP in 2006. There is a very large informal economy (according to INSTAT and other institutions, the informal sector may count for between $30 \%$ and $50 \%$ of the total economy).

Albania's trade imbalance is deep. The trade deficit was about $25 \%$ of the GDP in 2006. This deficit is mainly financed by remittances coming from a large number of emigrants working abroad.

State-owned entities (SOE) play a significant role in the economy of Albania, especially in the electricity and communications sectors, and the oil refinery industry. SOEs, being some of the largest entities in Albania, are important as public interest entities and as possible future privatization candidates. In addition, they provide the incumbent government the possible means of affecting the economy, also in time of elections. There is a wide believe that the incumbents tends to manipulate the elections, by "rewarding" the supportive regions/municipalities, which may be in the form of larger electricity supply for the "favourite electoral units (municipalities)" in times of electricity shortages (KESH, the Electricity Albanian Corporate, is owned and supervised by the government). Such assumptions may be a subject to econometrical analyses in another research work.

In Albania, still almost half of the population lives in rural areas. The mountainous areas, especially in northeastern Albania, are deeply undeveloped and poor.

The political life is mainly dominated by two political parties, Democratic and Socialist Party. Although the earlier is called as rightist and the latter as leftist, their differences are more based on geographical and (economic) clans' components rather than social strata, and are perceived as pragmatic rather than ideological (however, some ideological differences are discerned in their programs and less in their decisions). Because there is a wide agreement that the main Albanian political parties and governments have acted and act to large extent based on opportunistic approach, we found it reasonable to use the Nordhaus Opportunistic PBC Model as a bases of our research.

\section{PBC Theory and Empirical Background}

"It is pretty generally accepted that the popularity of political parties at election time is related to business conditions." [20]. It is obvious that the economic performance of a government determines to a large extent if it will be reelected, and therefore the economic factors influence political factors. There has been plenty of research and articles aiming at understanding and explaining the interrelation between economy and politics and the way the former affects the latter. Tibbitts does not specify weather the "good business years" or the "depression years" affect the opinion and decision of the voters, only when they are a result of respectively good and bad government performance. However it is clear that an improved economic situation 
(whether it is a result of professional leadership, or just a result of external factors) is reflected into electoral support for the incumbent, and the other way around, economic slow down, or crises, (whether it is a result of bad governance, or a result of other causes, such as whether conditions or international factors), will likely result in a change of government in elections years. In his research of the correlation of vote given to the party in power in different federal congressional districts, with selected points of business cycles, concluded that the party in power will receive more votes in elections following business expansion than in elections during business depression [20].

But the relation between economy and politics is wider and more complicated than just described by Tibbitts. There is a wide belief in Albania, and else where, that politicians would do almost any things to get into power and/or remain in power, including even starting wars. In this context, many would also believe that the incumbent would try to manipulate the economy (if they could) before elections aiming at staying in power.

The phenomena of (attempted) manipulation of the economy by the incumbent for electoral purpose, is called Political Business Cycles (PBC), introduced by William Nordhaus in his paper The Political Business Cycle, in year 1975.

The PBC model developed by Nordhaus (1975) opened the way for many following empirical and theoretical studies and publications and remains a point of reference. It suggests that incumbent attempts to manipulate the economy through the economic policies and instruments it possesses, in order to be reelected. According to Nordhaus theory, the incumbent will always attempt to generate $\mathrm{PBC}$, for political reasons, for the goal of wining elections. Therefore, his model is based on rational assumptions, and supports an opportunistic approach. Nordhaus focuses his empirical research on democratic countries, where elections are held regularly.

In his work he introduced a theoretical model based on the assumptions that there is a Phillips Curve economy (trade-off between inflation and unemployment), voters are backwardlooking (retrospective) with adaptive expectations and myopic, politicians are opportunistic and control a policy instrument, and the timing of elections is exogenously fixed. The implications of the early Nordhaus model are higher economic growth before elections as incumbent makes use of the short run Philips Curve and increased inflation after elections because of the fiscal and/or monetary expansion. After elections, the aggregate demand decreases which, which in turn reduces output and the rate of inflation.

Another major contribution in the Political Business Cycle theory, based on empirical studies, was given by Douglas A. Hibbs, who gave birth to the Partisan PBC theory. The Partisan PBC theory substantially differs from the Opportunistic PBC theory of Nordhaus, because it is based upon ideological approach rather than just an opportunistic approach focused only on reelections. He assumes that in general, political parties in most industrialized countries are distinguished to a large ex- tent by class, income and related socioeconomic characteristics. According to him, left wing, labor oriented governments pursue different policies from right wing governments, because in general they represent different "income and occupational status groups" with different preferences towards macroeconomic variables, including unemployment and inflation.

\subsection{Recent Empirical Research and Evidence for PBC}

One of the most interesting PBC research works was done by Alberto Alesina and Nouriel Roubin which were analysed data of three recent decades of 18 OECD countries analysing investigating the relation between main macroeconomic variables and elections results [2]. According to this study, there was no evidence of Opportunistic PBC of the Nordhaus type, either for output or for unemployment, except for two countries (Germany and New Zealand). However, the data showed electoral cycle on the inflation rate. The empirical findings were in line with the rational partisan theory, especially in countries with bi-partisan system, and less relevant in countries run by broad coalitions and unstable governments.

Also Krause and Méndez (2004) [13], analysing the data of 24 countries, found evidence suggesting higher relative preference towards stabilizing inflation from right wing governments, than the left wing governments.

There may be two explanations for the limited empirical support for the Nordhaus Opportunistic PBC on growth and unemployment. First of all, "rational" voters limit such approach, and therefore the policymakers, being aware of this fact, do not try to generate Opportunistic PBC policies. Second, it is not an easy task to generate expansions well calculated and timed for elections [2].

Evidence of PBC was also found in less developed and democratic countries. Daniel Treisman and Vladimir Gimpelsen made a research on the existence of PBC in Russia (2001), finding evidence in support of it. In his study, Asutay (2004) provided clear evidence for the presence of PBC in Turkey. The incumbent in Turkey has used fiscal and monetary policy instruments to create PBC in order to improve the chances of being reelected.

\subsection{Endogenous versus Exogenous Set Election Dates}

Nordhaus (1975) does not make a distinction between endogenous and exogenous election timing. Nevertheless, the way the election date is set may have a decisive effect on the predictability of the model.

In some countries, the election timing is imposed constitutionally (ie. in US, Presidential Elections every 4 years). But this is not the case for all (or most) consolidated and new democracies. According to Lachler (1982), if the elections timing is not set for a fixed date by the constitution, the incumbent can call early elections for political, economic and/or social reasons. In this context, the incumbent has information advantage, by knowing alone when elections could take place. The opportunis- 
tic government may decide to call for early elections during high economic performance (which should not necessarily be a result of good governance), and benefit (i.e. win a larger majority).

As claimed by Ito and Park "the incumbent government does not manipulate the economy, but waits for positive nongovernment sector supply shocks (high growth, low inflation) to call an election" (Ito and Park, 1988: 234).

In the case of Albania (parliamentary republic), the constitution does not set the fix date of (parliamentary) elections. Although it imposes elections every four years, allows the incumbent to call for early elections. During the short history of its fragile democracy and market economy, starting from 1992, there has been only one case that early parliamentary elections were called (1997 crises).

The local elections of February 2007, however, are an interesting example. These elections were seen as very important by both incumbent and opposition, as a referendum for the government, elected in year 2005. Although they should be held in the end of year 2006, the opposition pushed for a delay (within constitutional limits), so that the election timing could converge with the electricity shortages, caused by both dry whether and close down of Bulgarian reactors (opposition presented other pretext for pushing for this delay). The electricity shortages, caused by external major factors, led to dissatisfactions of households (that in some areas lacked electricity for more than 6 hours a day), higher costs for businesses, and in turn lower economic performance (miniature of supply driven inflation of the 1970s in the west, that also questioned the Phillips Curve). The incumbent lost the elections in larger cities. It is hard or impossible to show econometrically to what extent the elections result was affected by these reaction chain, however, there is a wide belief that the electricity crises and its "by-products" did influence the voting decisions.

\section{Searching for PBC in Albania}

\subsection{Theoretic modelling}

We assume an Opportunistic Political Business Cycle (OPBC) model for Albania. There is a wide consensus in Albania that political parties follow an opportunistic pattern instead of ideological one. There have been cases in the Albanian short democratic history the right-wing governments promote leftist reforms and vice versa. There is a socialist "tradition": the very close relationship between political power and wealth. In almost every former socialist country the market-based legal system had been introduced, but in reality policy is made on the basis of "old reflexes".

As we already saw in the previous chapter, Nordhaus (1975), based on theoretical and empirical findings, claims that the opportunistic governments attempt to manipulate the economy, by using the economic instruments they possess in order to achieve macroeconomic outcomes that are attractive for the voters, in order to enhance chances of being reelected. Hence, they try to engineer growth prior to election by expanding controlled eco- nomic instruments and contract them after the election, causing artificial business cycles, which very likely seem to be inefficient for the economy.

Inspired by this model, we seek to statistically find if there is PBC in Albania caused by opportunistic incumbent governments. We will analyse the instruments we have investigated for political manipulation, macroeconomic outcomes, methodology we have used and the results that we have achieved. In this section we briefly present the assumptions and implications of Nordhaus (1975) theoretic.

The assumptions underlying Nordhaus "Political Business Cycle" are as follows:

\section{- The expectations of the voters are adaptive}

In Nordhaus' model (1975) is assumed that the expectations of the voters are adaptive. That means that the expectations of the voters regarding the government performance and the prospect of the economy are formed adaptively, taking the past values and the most recent values of economic variables as an index for government performance. That is formally represented as:

$$
v_{t}=\pi_{t-1}+\lambda\left(v_{t-1}-\pi_{t-1}\right) \quad 0<\lambda<1
$$

where $v$ is the rate of expected inflation and $\pi$ is the actual inflation rate

\section{- The economy can be represented by a Phillips Curve}

There is a general agreement among economists that within an economy there is a trade-off between the levels of unemployment and the rate of inflation (although that may not always be the case). Thus, Nordhaus (1975) assumes the economy can be modelled by a Phillips Curve. Taking into account the first assumption, Nordhaus employs an expectations-augmented version of the Phillips Curve. Hence, the dynamic economic system upon which Nordhaus (1975) builds his opportunistic political cycle model can formally be expressed as:

$$
\left\{\begin{aligned}
\pi_{t} & =f\left(u_{t}\right)+\gamma v_{t} \\
v_{t} & =\pi_{t-1}+\lambda\left(v_{t-1}-\pi_{t-1}\right)
\end{aligned}\right.
$$

where $u$ is the rate of unemployment.

\section{- Voters are myopic}

The model assumes that voters judge the incumbent by evaluating positively low unemployment and low inflation, but Nordhaus (1975) introduces the possibility that voters do not take simple averages of economic variables over the last electoral period, but have a decaying "memory" of past events. On election day, the memory of recent events looms larger than that of old (bad) times. In this case, the aggregate vote function can be described as:

$$
V_{\theta}=\int_{0}^{\theta} g\left(u_{t} \pi_{t}\right) e^{\mu t} d t
$$

where $g\left(u_{t} \pi_{t}\right)$ is the vote function used in the static case or it can be seen as the preference function of the electorate $U=$ 
$g\left(u_{t}, \pi_{t}\right)$ which depends on the macroeconomic situation in a certain time, $\mu$ is the rate of decay of voters' memories, and $\theta$ is the length of electoral period.

\section{- Politicians control a policy instrument}

To be able to manipulate the economy for electoral purposes, the government should have (some) control of policy instruments, such as fiscal and/or monetary policies, which have direct impact on macroeconomic outcomes that affect the individuals (i.e. unemployment). This can take place when such policies alter aggregate demand.

\section{- The timing of elections is exogenously fixed}

Nordhaus' model is based on exogenously determined election timing, but as we have already seen in the previous chapter, this may not always be the case.

\section{- Politicians are opportunistic}

The assumption is that the main or only purpose of the government is re-election, and they use the means they have, including economic policy instruments, to be re-elected. Formally the behaviour of opportunistic politicians trying to maximize the votes can be expressed as:

$$
\max _{\left\{u_{t}, \pi_{t}\right\}} V_{\theta}\left(u_{t}, \pi_{t}\right)=\int_{0}^{\theta} g\left(u_{t} \pi_{t}\right) e^{\mu t} d t
$$

subject to the economic constrains:

$$
\left\{\begin{aligned}
\pi_{t} & =f\left(u_{t}\right)+\gamma v_{t} \\
v_{t} & =\pi_{t-1}+\lambda\left(v_{t-1}-\pi_{t-1}\right)
\end{aligned}\right.
$$

where $V_{\theta}\left(u_{t}, \pi_{t}\right)$ is the aggregate voting of the electorate expressed as a function of the macro-economic situation. The system of constrains is the augmented Philips curve by which the economy is modelled.

Under these assumptions the implications of the Nordhaus model are the following:

1 All governments follow the same policy. They stimulate economic growth before the elections to make use of short run Philips Curve

2 Inflation will increase during and after election time because of economic expansion. Later, the inflation is reduced through contractionary policies.

Hence, in the next sections we explain the empirical tests we made to the above mentioned implications of the OPBC Nordhaus theoretic in the case of Albania. We test them both in an "indirect and direct way". We test these implications "indirectly" by investigating the patterns of fiscal and monetary instruments which may be manipulated by incumbents in elections' time and we test them "directly" by investigating the patterns of the macroeconomic indicators, such as inflation, GDP, and unemployment.

\subsection{Variables and Data specifications}

Within the OPBC model framework we expect that the government may follow expansionary fiscal and monetary policy to reduce unemployment and increase output before/during elections, and as a result of this expansionary economic policy, the inflation may increase during/after elections. Naturally, we will investigate and analyse the economic policy instruments literally fiscal and monetary instruments. We will statistically test for PBC in fiscal and monetary instruments, as well as in the related main economic outcomes; unemployment, output and inflation. Below we list the set of all these variables (policy instruments and economic indicators):

\section{Fiscal instruments:}

- Public investment expenditure

- Government expenditures on compensation of employees

- Unemployment insurance benefits

- Subsidies

- Social assistance

- Social insurance outlays

Monetary instruments:

- Monetary aggregate M1

- Monetary aggregate M2

Macroeconomic outcomes:

- Gross Domestic Product

- Unemployment

- Inflation

The data for the variables mentioned above are monthly time series beginning from January, 1998 to March, 2007, including 111 observations. There is exception for the data of GDP and unemployment which are available only quarterly. The data were collected from the Ministry of Finance, (Central) Bank of Albania and Albanian Institute of Statistics (INSTAT).

The period before 1998 was not taken into consideration primary for two reasons. First, there is a lack of data and/or the quality is not reliable. Second, elections, economic, political and institutional framework followed a chaotic and abnormal pattern during those years. It was possible (easier) to win the elections by (police) force during those years, and therefore there was little (if any) incentive for the incumbent to use macroeconomic polices to win elections.

During the analysed period there took place two parliamentary elections, namely June 24, 2001 and July 3, 2005 and three local elections, namely 1 October 2000, 12 October 200318 February 2007. The local elections were considered significant also because they were seen as a test for the participating political forces and as a referendum for the central government. 


\subsection{Specifications of empirical tests}

Surveying the literature of the empirical works on this field we decided to use the Intervention Analysis [4] methodology for constructing a statistical model in our study. Many other well known researchers on the field such as McCallum [14], Hibbs [11]Alesina and Sachs (1988), Alesina and Roubini [2] have used Intervention Analysis in empirical studies of this kind.

Given a known intervention should be investigated if there is evidence of change in the series of the kind expected, and, if so, what can be said of the nature and magnitude of the change (Box-Tiao, 1975). Statistically speaking: A test of the null hypothesis that a postulated event caused a change in the social processes measured as a time-series.

The rationale for using this econometrical tool is that the political manipulation of the economy through fiscal and monetary instruments can be considered as an intervention which yields cyclical shifts in the mean value of the time-series of the particular policy variable or the macroeconomic outcomes. Thus in our research work, the intervention analysis aims to search if the elections can render additional explanations in the relevant fiscal, monetary policy instrument and in macroeconomic indicators time-series.

In this paper we test the hypothesis of the existence of changes in the above mentioned fiscal and monetary instruments and macroeconomic time series during the elections timing, consistent with Nordhaus' theory. Basically the test proceeds by subjecting the monthly seasonally adjusted time series of these variables to a Box-Tiao (1975) intervention analysis. The BoxTiao technique basically consists in fitting a time series as a sum of an autoregressive-moving average (ARMA) process and an intervention term; here the intervention term models the time distance to the election day. Hibbs (1977) offers a good introduction to the Box-Tiao technique.

A simple formal representation of the intervention analysis is:

$$
z_{t}=\mu+I_{t}+N_{t}
$$

where $\mu$ denotes the mean level, the term $I_{t}$ denotes the intervention effect and $N_{t}$ denotes the noise of the time series which is modelled using a suitable $\operatorname{ARMA}(\mathrm{p}, \mathrm{q})$ time series model,

$N_{t}=\phi_{1} N_{t-1}+\ldots+\phi_{p} N_{t-p}+E_{t}-\theta_{1} E_{t-1}+\ldots+\theta_{p} E_{t-q}$

where $E_{t}$ denotes an independent error sequence.

The simplest, which corresponds to the $t$-test in a non-time series setting, is the Intervention term/variable, which in this case takes the form of a Pulse Intervention which is an abrupt jump in the series and then a gradual decline at the normal level of the series. Formally the pulse intervention term can be expressed as:

$$
I_{t}=\omega_{0} P_{t}^{(T)}
$$

where $P_{t}^{(T)}$ is a pulse function,

$$
P_{t}^{(T)}= \begin{cases}0 & t \neq T \\ 1 & t=T\end{cases}
$$

The parameter $\omega_{0}$ measures the change caused by the intervention and is estimated along with the ARMA time series component. The estimation procedure provides an estimate of $\omega_{0}$ and a confidence interval for the parameter. In our case the dependent variable $z_{t}$ is the fiscal or monetary instrument or the macro-economic indicator that is assumed to be affected because of elections. The intervention variable $I_{t}$ is expressed as a binary variable (dummy variable) indicating a specific time prior to election, as shown below. And the noise component of each specific dependent variable $N_{t}$ is modelled by an appropriate $\operatorname{ARIMA}(p, d, q)$ found by following Box-Jenkins (BJ) Methodology (1970) as explained in more detail below.

Hence the application of the Intervention Analysis in this types of studies aims to search if the elections can render additional explanations in the relevant fiscal and monetary policy instrument and macro-economic time-series.

We have created six political variables $\left(I_{t}\right)$ to capture the impact of the election on fiscal and monetary policy instruments and macroeconomic outcomes and also on macro-economic indicators. The first four political variables tend to capture the manipulation of the economic policy instruments and consequently the macroeconomic outcomes by the opportunistic incumbent before elections. The fifth and sixth political variables intend to catch the contraction of the fiscal and monetary policy instruments and macroeconomic outcomes after elections.

Note: For convenience we have denote $P_{t}^{(T)}$ with PD standing for Political Dummy

$$
\begin{aligned}
& P D 1=\left\{\begin{array}{l}
1-\text { for the three months prior to election } \\
0-\text { otherwise }
\end{array}\right. \\
& P D 2=\left\{\begin{array}{l}
1-\text { for the six months prior to election } \\
0-\text { otherwise }
\end{array}\right. \\
& P D 3=\left\{\begin{array}{l}
1-\text { for the nine months prior to election } \\
0-\text { otherwise }
\end{array}\right. \\
& P D 4=\left\{\begin{array}{l}
1-\text { for the twelve months prior to election } \\
0-\text { otherwise }
\end{array}\right. \\
& P D 5=\left\{\begin{array}{l}
1-\text { for the three months after the election } \\
0-\text { otherwise }
\end{array}\right. \\
& P D 6=\left\{\begin{array}{l}
1-\text { for the six months after the election } \\
0-\text { otherwise }
\end{array}\right.
\end{aligned}
$$

Note: We have shown here the definition of these variables in monthly terms as we have used mostly monthly time-series for the variables (instruments) under consideration. The variables expressed in quarterly time series were treated similarly.

We have used separate PD variables for parliamentary and local elections attempting to capture separately the effects of each kind of elections regarding the cyclical behaviour of each specific policy instrument and macroeconomic indicator. 
Regarding the expected signs of the policy variables, according to Nordhaus' opportunistic model, we expected the coefficients of pre-election variables, PD1, PD2, PD3, and PD4, to have positive signs, implying pre-election expansion of policy instruments. On the other hand, post-election variables PD5 and PD6 are expected to have negative sign, implying contraction in the post-election period.

In the case of inflation, post-election variable should have a positive sign as a result of the pre-election expansionary economic policies.

\subsubsection{Estimation of the empirical model}

Recent developments in time-series econometrics have yielded significant implications for econometrics application. A crucial point of these developments has been the robustness of OLS estimators. Due to econometrics time series properties of social processes the OLS estimates may yield spurious regression (Granger and Newbold, 1974). As shown by Price (1998), most of macroeconomic time series follow a long-run trend. One explanation for such an occurrence can be the trend and a changing variance inherent in these time series processes. Hence the implication for this would be the invalidity of the significance test applied on OLS estimates. The existence of a time trend and a changing variance in a time series process is widely known as non-stationary. When a time series is to be modelled by an Autoregressive Moving Average model (ARMA), as we are doing within the Intervention Analysis framework, such a time series must first be transformed to a stationary one [5].

In order to estimate the above mentioned empirical model for each of the variables under consideration we have undergone a two-stage process. First we estimate an appropriate ARMA model for each of the depended variables time series and then we implement the political dummy variables individually and re-estimate the model as a whole. For each of the instruments' time series we will end up having six estimated models referring to parliamentary elections and six to local elections. Each of the models has the same $\operatorname{ARMA}(p, q)$ part and one of the $P D_{i}$ variables $(i=1,2, \ldots, 6)$ which attempt to capture the election effects on fiscal and monetary instruments and on the macroeconomic indicators.

In the first stage, we have followed precisely the Box-Jenkins (BJ) Methodology (1970). In the beginning of the process, the first step for each time series was removing the seasonal patterns when they were present. All of the seasonal adjustments are computed with the help of DEMETRA software ${ }^{2}$. The next step was to carefully investigate on the stationary of each specific time series as a necessity in further steps. In case a time series appeared to be non-stationary, the appropriate transformations were made. Whenever non-stationarity was evident in a time series, we performed first order difference transformation on the

\footnotetext{
${ }^{2}$ DEMETRA is a standard software used by EUROSTAT to seasonally adjust every kind of EU figures.
}

original series. In every case the first order difference of the original time series resulted from all the relevant tests to be stationary ${ }^{3}$. To test for the stationarity of the time series and their transformations, the unit root test, specifically the Augmented Dickey Fuller test, was employed.

After ensuring the stationarity of time-series, the study is modelled as ARMA (AutoRegressive Moving Averages) based on Box-Tiao's (1975) intervention analysis. By modelling through ARMA it is possible to prove if elections can explain the changes taking place in each policy instrument, in addition to the past history of each variable and the random error term. For this process the identification of $\operatorname{ARMA}(p, q)$ benchmark models is necessary. To find the "best" ARMA model for each time series we are straightforwardly based on Box-Jenkins methodology (1970). Hence, in order to model as an ARMA each of the time series, we went throught an iterative process of identification, estimation and diagnostic checking of several ARMA models until we found the most plausible one, deemed as the "best" for each series".

In the second stage we individually incorporated each of the political dummy variables in the ARMA model tentatively found in the first stage and re-estimated the whole model now with an additional incorporated $P D i$. The political dummy variables aim at capturing the impact of elections, to test whether elections have any impact on the econometric time-series utilized by this study in addition to each variable's past value and its respective error term. Thus, the impact of elections is considered to be an intervention or shock in the determination of the value of a variable by forcing the value of the variable to shift during the intervention or shock periods. The statistical significance of the political dummy variables is tested using $t$-test. Consequently, if the coefficient of the political dummy variable is statistically significant and possesses the expected sign it can be inferred that political manipulation exists and elections affected the fiscal, monetary policy instrument or macro-economic time-series.

\subsection{Empirical Results of PBC Analyses in Albania}

We investigate the possible existence of PBC pattern in economic instruments variables, including both fiscal and monetary variables, and in macroeconomic outcomes variables.

\subsubsection{Analyses of Fiscal Economic Instruments Variables}

In the context of specifications explained above, we will model the monthly public expenditures by category, undertaken by the governments for 1998M1-2007M3 including the effect of the 2001 and 2005 parliamentary elections, and 2000, 2003, 2007 local elections. We aim at estimating the significance of

\footnotetext{
3 The $n$ order difference is a strongly recommended efficient approach in most of the literature of transforming one time series from non-stationary to a stationary one

${ }^{4}$ Gujarati (2003) makes a simple and clear explanation of the Box - Jenkins Methodology
} 
the political variables so that we can explain the changes that take place in public expenditures.

\section{- Public investment expenditure in parliamentary (general) and local election}

Since the time series of this instrument obviously showed a seasonal pattern, first we seasonally adjusted this time series. Then we investigated the stationarity of the series employing all the relevant tests (unit root test-Augmented Dickey-Fuller test, ACF, PACF). The seasonally adjusted figures of public investments are not differenced at any order as from all the tests it resulted to be a stationary time-series. Then we tentatively found "the best" ARMA model for this time series which is an $\operatorname{ARMA}(0,1)$ or a pure moving average with a lag one, $\operatorname{MA}(1)^{5}$. The $p$-values of the political dummy variables indicate the significance level of these variables.

After we went through all the steps of the methodology as explained above, we had the following results. The estimated coefficients before pre-parliamentary election variables, PD1, PD2, PD3 and PD4 have a positive sign as a priori expected. PD1 is significant at $5 \%$ level (indicated by $p$-value) strongly implying that the government do increase this instrument nearly prior the general parliamentary elections. On the other hand, the post-election variables, PD5 and PD6, are significantly negative at $5 \%$ level, implying that the government investment expenditure in the post-election period decrease to compensate for the increased spending of the pre-election period, as theory predicts.

The public investments in local elections follow a similar picture as in parliamentary ones. All the PD variables prior to elections have coefficients with a positive sign, as expected, with PD2 significant at 5\% and PD4 at $10 \%$. The post-election variables, PD5 and PD6, have negative signs although not significant.

Public investment, in addition to the direct benefits to the potential voters, can be utilized to make show campaigns from the incumbent (it is common to see ministers and mayors before elections inaugurating new roads, schools, etc.).

- Expenditure on compensation of employees in parliamentary and local election (Wages + Social insurance contributions)

The characteristics: Seasonally adjusted, first-order difference, best model ARMA $(0,1)$.

Regarding the parliamentary elections all the pre-elections variable coefficients result with the expected (positive) sign and PD2, PD3, PD4 coefficients are statistically significant at 5\% level.

The first post-elections variable's coefficient, PD5 is not negative, contrary to our expectations; however it marks an evident decrease in comparison to PD4. The second post-elections

\footnotetext{
5 The same general procedure is followed in all the other time series considered in this study. Further on we briefly report the results of this procedure referring as "the characteristics" of the time series.
}

variable's coefficient PD6 is negative, as expected but not significant. These results imply that governments do manipulate compensation of employees' expenditure prior to parliamentary elections increasing them and they do cut them short after elections although for the second statement we are not statistically sure.

All the pre-local elections variables' coefficients result in opposite signs as expected. Furthermore three of them are significant. Consequently, we can conclude that the governments do not attempt to manipulate this instrument at local elections maybe because the incumbent does not consider the local elections as important as the parliamentary elections, or because they may focus more on other instruments, which may be more efficient for local elections, such as public investment (i.e. constructing roads) in the targeted municipalities. Hence the behaviour of incumbents in this case may be such that "they take some money from the compensation of employee's pool and put them to the public investment's pool".

\section{- Subsidies in parliamentary and local elections}

The characteristics: Seasonally adjusted, first-order difference, best model ARMA $(0,1)$.

Most pre-elections variables' coefficients in both parliamentary and local have a positive sign however they are statistically insignificant implying that subsidies have not been used as a "tool of government" prior to both types of elections.

\section{- Unemployment insurance benefits in parliamentary and local elections}

The characteristics: Seasonally adjusted, first-order difference, best model ARMA $(0,1)$.

Regarding parliamentary elections almost all the pre and postelections' coefficients have the expected sign but only PD6 is significant at $10 \%$. Consequently, we can not say anything with certainty regarding the opportunistic manipulation of this instrument.

Different from general elections, in local elections appears another view regarding the unemployment insurance benefits. The pre-elections' coefficients here are with the expected sign and significant. Two of them, PD2 and PD4 are significant at 5\% level. The post-elections' variable coefficients, PD5 and PD6, are contrary to theoretic expectations; since they are positive (PD5 is significant at 5\%). We can conclude that the governments do increase this kind of expenditures prior to local elections in order to attract the voters, and naturally may find it difficult/impossible to reduce them back to the previous levels.

\section{- Social assistance in parliamentary and local elections}

The characteristics: Seasonally adjusted, first-order difference, best model: ARMA $(0,1)$.

The econometric analyses of the social assistance variable in both types of elections follow a similar pattern with the unemployment insurance benefits variable. There is no statistically 
significant increase in parliamentary elections while there is statistically significant increase in local ones. The post-elections' variables coefficients, PD5 and PD6, appear with the negative sign as predicted by theory, however significant. So we can conclude the variables of "Social assistance" have been used by governments as a tool of electorate manipulation, as in the case of "Unemployment insurance benefits".

\section{- Deficit in parliamentary and local elections}

The characteristics: Seasonally adjusted, first-order difference, best model: ARMA $(0,1)$

In parliamentary elections', the pre-elections variable coefficients are with a positive sign, as expected, but statistically insignificant. In local elections, these variable coefficients are with a negative sign, opposite to what was expected. This makes us conclude that governments do not engage significantly in higher deficits prior to general or local elections. One explanation for this attitude may be the restrictions posed by the IMF. Therefore we may conclude, that although the governments significantly increase some of the expenditure items in elections time, they are discrete regarding deficit. Or, the increased expenditures may be covered by higher revenues (i.e. tax collections) before elections. An interesting result that needs explanations is the fact that PD5 and PD6 result to be with a positive sign and significant at $5 \%$ after the general elections.

\subsubsection{Analyses of Monetary Economic Instruments Vari- ables}

The statistical analyses, makes us conclude that the incumbent does not manipulate Monetary Policy. It is not a coincidence that the incumbent does not engage in Monetary PBC, because the Central Bank of Albania enjoys a relatively high level of independence.

\section{- Monetary aggregate M1 in parliamentary and local elections}

The characteristics: Seasonally adjusted, first-order difference, best model: ARMA(1,0)

M1 is statistically insignificant in most cases in both parliamentary and local elections, except for PD5 in parliamentary elections. PD5 in parliamentary elections is significant but with a positive sign, opposite to what the theory predicts. These results confirm the fact that the Central Bank of Albania is not engaged in PBC. M1 follows the same pattern as the deficit which is positive and significant in post-parliamentary elections period.

\section{- Monetary aggregate M2 in parliamentary elections}

The characteristics: Seasonally adjusted, first-order difference, best model: ARMA $(0,0)$

Note: Although the time series in this case can not be appropriately modelled by any $\operatorname{ARMA}(p, d)$ where $(p, d \neq 0)$ the outcomes of Intervention Analysis still hold the same.

Similar to M1, also M2 is statistically insignificant in most cases in both parliamentary and local elections.

\subsubsection{Analyses of Macroeconomic Outcomes Variables}

We have analysed the main macroeconomic outcomes; GDP, inflation (through CPI) and unemployment. As already stated earlier, we expect that the incumbent attempts to manipulate the economy, to increase the output and unemployment before/during elections, through fiscal and/or monetary expansion (in our case, fiscal expansion). In addition to the (possible) achievement of intended outcomes (lower unemployment and higher output), normally such policies will result in higher inflation after elections.

\section{- Unemployment in parliamentary elections}

The characteristics: Seasonally adjusted, first-order difference, best model: $\operatorname{ARMA}(0,0)$

Note: the data for unemployment are quarterly data from 1998Q1-2007Q1

The unemployment is reduced before both types of elections, as predicted by the theory. However, the unemployment reduction is statistically significant only in parliamentary elections as reflected by PD2 and PD3 respectively significant at 10 and 5 percent level.

\section{- GDP in parliamentary and local elections}

The characteristics: Seasonally adjusted, first-order difference, best model: ARMA $(0,0)$

Note: the data for QGDP are quarterly data from 2001Q12006Q4 (Experimental figures-INSTAT).

The signs of the coefficients in all the cases are exactly like the theory predicts, in both general and local elections, but they are not significant except for two cases, PD5 in parliamentary and PD2 in local. Given the limited number of observations, we may attribute to that fact the insignificance of the coefficients and judging from the sings of the coefficients we might imply that the manipulations of the government of fiscal instruments do effect the GDP, which also corresponds to the results of unemployment.

\section{- Consumer Price Index (CPI) in parliamentary elections}

The characteristics: Seasonally adjusted, first-order difference, best model: ARMA $(0,1)$

CPI does not significantly change during and after parliamentary and local elections. This stability of CPI may be attributed to the "mature" policies followed by the Central Bank.

\subsection{Reflections on PBC Theoretic and Empirical Findings}

The incumbent in Albania, as elsewhere tends to use the economic instruments it possesses to manipulate the economy for electoral purposes. The use of expansionary policies by the incumbent may not necessarily lead to statistically increased unemployment and output. In our case, although there was a change of these macroeconomic variables in the expected directions, the changes were not statistically significant, despite the fact that public expenditures (fiscal policy) were in general 
statistically increased before elections. There might be several explanations.

First, the economic structure and situation and the transmission mechanism may not reflect the fiscal expansion into significantly higher output and lower unemployment.

Second, there might be other factors that may offset or counterbalance the effect of the expansionary economic policies. Consumer and private companies' preferences may be characterized by cycles which may timely converge with the elections cycles. Before parliamentary elections, there are usually "economic uncertainties" among many/most consumers and private companies, because in the case of Albania, where there is a weak institutional framework, it is common that the governmental changes are associated with huge changes in the public administration staff, sometimes going down to police and high school teachers. Moreover the new government official, may try to favour "supportive client businesses" and "punish" businesses associated with the other political forces. Consequently, there may be reduced investments and household consumption levels, and overall aggregate demand, which may counterbalance the increased aggregate demand, resulting from expansionary fiscal policy. Another explanation is that the government may try to increase taxes (revenues) before elections to finance for the increased expenditures, while still maintaining low deficit. In this case, the fiscal manipulation takes the form of pure distributive maneuver, "taking money" from relatively few businesses and distributing them to the many voters.

Hibbs assumes that political parities have ideological orientation and follow policies in line with the preferences of their main constituencies. There is a strong argument against it. Even in the case of parties following ideological orientation in line with the core part of the voters, they may do so in case they are convinced that if they move apart from their (ideological) line, they may loose their electorate (there is therefore an opportunistic element). Moreover, there is evidence, that there are cases that ideologically oriented parties, may ignore the interests of their "hard line" supporters (voters), although these interests may be in line (or neutral) with the ideological orientation, because the party leaders know that their "hard line" supporters would not vote for another party, anyway. Instead they may orient certain policies toward "ideologically un-oriented" or "politically undetermined" voters that could in turn give their votes to that (incumbent) party. That can particularly be the case of policies, that can not (necessarily) be classified as leftist, rightist, or have any ideological characterization at all, such as the decision to make a certain public investment in this or that geographical area, or decision to increase the wages of this or that (public) sector. The decision of increasing overall public investment or wages may be a matter of ideological orientation, but for a given level of investment and wage budget, choosing the areas or sector, may not necessarily justified by ideological factors.

Once a high socialist government official in Albania was asked by an advisor to increase the wages of the military per- sonal, because their majority is widely believed to be leftist, he answered that there was no reason for increasing their wages, because either way they would vote for the (same) socialist party.

Another interesting example is the geographically orientated electorates. In Albania, the Socialist Party enjoys considerably higher support in the south of Albania, and the other way around, the Democratic Party (right-wing), has considerably more voters in the north of Albania (these are the two largest parties in Albania). There are two implications. First, each party, once in power, may make decisions and follow policies, which although in line with their ideological orientation, still contain opportunistic elements, in the context of sector and regional focus, in terms of choosing the region and sector to receive the higher benefits, which should naturally converge with those containing the highest electoral support.

Second implication is that the government may not consider it reasonable to "waste" resources for "strong hold" (geographic) electoral areas, which do not normally change their voting pattern, but shift their recourses to those electoral areas that can change their overall support. An evidence for this argument, is provided by the fact that the present government dominated by the Democratic Party, supplied less electricity ${ }^{6}$ to Tropoja (northern city) than the previous Socialist government, which is a "strong hold" of the Democratic Party, because it is widely believed that the vast majority of that city will always vote for that (Democratic) party, as in the past. Instead, they supplied more electricity to areas that traditionally supported the Socialist Party, but that on occasions had voted for the Democratic Party, like the city of Gjirokastra (city of Gjirokastra, with a large Socialist electorate, elected a MP of the Democratic Party last elections).

More empirical and formal evidence for these claims are needed, which can be subject to another research undertaking.

\section{Conclusions}

The incumbent is willing to use a lot of means (if not every means) to remain in power. We have already seen plenty of theoretical and empirical evidence in support of the view that politicians often attempt to manipulate the economy, to "buy voters", creating PBCs, which although may work in the short term, in the long term may be a source of economic instability or inefficiency.

In our search for PBC in Albania, we found convincing evidence that the incumbent tries to manipulate the economy. There is a statistically significant increase of public expenditures before elections, in an attempt to improve the overall economic situation, through public investments, and directly benefit the voters through increased transfers to the population, such as unemployment and social insurance benefits.

\footnotetext{
${ }^{6} \mathrm{KESH}$, the Albanian Electricity Corporate, is a public company run by the government
} 
Regarding the macroeconomic outputs, we have found evidence of PBC in GDP and unemployment, but not in inflation. The fiscal expansionary policy before elections, leads to higher GDP and lower unemployment before/during elections. However, the inflation does not significantly increase as expected. It is not a coincidence that the incumbent does not engage in Monetary PBC and that inflation does not alter significantly during elections, because the Central Bank enjoys a relatively high level of independence and it may be considered the centre of economic policy in Albania.

The fiscal expansion may not always lead to significantly higher output and employment because the transmission mechanisms may not be predictable and controllable, and because other cycles may occur simultaneously but independently of economic instruments.

Another view is that the incumbent may orient its "electorate buying" policies according to geographical aspects and not only "social strata" aspects, as predicted by Hibbs. This spatial element of our analysis opens a new window for research.

\section{References}

1 Alesina A, Jerey S, Political Parties and the Business Cycle in the United States, Journal of Money, Credit and Banking 20 (1998), 63-82.

2 Alesina Alberto and Nouriel Roubini, Political Cycles in OECD Economies, Review of Economic Studies 59 (1992), 663-88.

3 Asutay M, Searching For Opportunistic Political Business Cycles in Turkey, 2004.

4 Box GEP, Tiao GC, Intervention analysis with applications to economic and environmental problems, J. Am. Stat. Assoc. 70 (1975), 70-79.

5 Box GEP, Jenkins GM, Time Series Analysis, Forecasting and Control (1976), 553. Holden-Day Inc.

6 Gimpelson V, Political Business Cycles and Russian Elections, or the Manipulations of "Chudar", British Journal of Political Science 31 (2001), 22546.

7 Granger CWJ, Newbold P, Spurious regressions in econometrics, Journal of Econometrics 2 (1974), 111-120.

8 Gujarati DN, Basic Econometrics, McGraw Hill, New York, 2003. Fourth Edition.

9 Douglas AH Jr., The American Political Science Review 71 (1977), no. 4, 1467-1487.

10 Hallerberg M, de Souza Lúcio Vinhas, The Political Business Cycles of EU Accession Countries, 2000. Tinbergen Institute Discussion Paper.

11 Hibbs Douglas A. Jr., The American Political Economy: Macroeconomics and Electoral Politics, Cambridge, MA: Harvard University Press, 1987.

12 _ Voting and the Macroeconomy, 2006.

13 Krause S, Méndez F, Policy Makers' Preferences, Party Ideology and the Political Business Cycle, Department of Economics, Emory University, and Department of Economics, University of Arkansas, 2004.

14 McCallum B, The political Business Cycle: An Empirical Test, Southern Economic Journal 44 (1978), 504-515.

15 Phelps ES, The Role of Monetary Policy, American Economic Review 58, no. 1.

16 Phelps Edmund S, Phillips Curves, Expectations of Inflation and Optimal Employment over Time, Economica NS 34 (1967), no. 3, 254-81.

17 Phillips AWH, The relation between unemployment and the rate of change of money wage rates in the United Kingdom 1861-1957, Economica 25 (1958), 283-299.

18 Price S, Cointegration and Modelling the Long Run, 1998.
19 Suzuki M, Political Business Cycles in the Public Mind, The American political science review 86 (1992), no. 04.

20 Tibbitts Clark, Majority Votes and the Business Cycle, The American Journal of Sociology 36 (Jan. 1931), no. 4, 596-606.

21 Albanian Institute of Statistics, available at www. instat.gov.al.

22 Nordhaus W, The Political Business Cycle, Review of Economic Studies 42 (1975).

23 Treisman D, Gimpelson V, Political Business Cycles and Russian Elections, or the Manipulation of the "Chudar", British Journal of Political Science 31 (2001).

24 Lachler V, On political business cycles with endogenous elections dates, Journal of public economics 17 (1982).

25 Ito T, Park JH, Political business cycles in the parliamentary system, Economics Letters 27 (1988). 
Tab. 1. Sesonally adjusted public investment in parlamentary elections Depended variable: Public Investments (PubInv)

\begin{tabular}{|c|c|c|c|c|c|c|c|c|c|c|c|c|}
\hline \multirow{2}{*}{$\begin{array}{l}\text { Model Type } \\
\qquad \operatorname{ARIMA}(0,0,1)\end{array}$} & \multicolumn{2}{|c|}{ Model 1} & \multicolumn{2}{|c|}{ Model 2} & \multicolumn{2}{|c|}{ Model 3} & \multicolumn{2}{|c|}{ Model 4} & \multicolumn{2}{|c|}{ Model 5} & \multicolumn{2}{|c|}{ Model 6} \\
\hline & Coeff. & Sig. & Coeff. & Sig. & Coeff. & Sig. & Coeff. & Sig. & Coeff. & Sig. & Coeff. & Sig. \\
\hline Constant & 2855.64 & 0.000 & 2845.17 & 0.000 & 2826.09 & 0.000 & 2793.09 & 0.000 & 42.09 & 0.039 & 48.08 & 0.029 \\
\hline Publnv (MA1) & -0.49 & 0.000 & -0.46 & 0.000 & -0.45 & 0.000 & -0.45 & 0.000 & 0.84 & 0.000 & 0.83 & 0.000 \\
\hline PD1 & 1100.97 & 0.034 & & & & & & & & & & \\
\hline PD2 & & & 661.92 & 0.110 & & & & & & & & \\
\hline PD3 & & & & & 560.08 & 0.116 & & & & & & \\
\hline PD4 & & & & & & & 574.31 & 0.074 & & & & \\
\hline PD5 & & & & & & & & & -399.68 & 0.023 & & \\
\hline PD6 & & & & & & & & & & & -248.25 & 0.013 \\
\hline \multicolumn{13}{|c|}{ Diagnostic tests } \\
\hline Stationary R-squared & & 0.180 & & 0.180 & & 0.179 & & 0.185 & & 0.274 & & 0.281 \\
\hline R-squared & & 0.180 & & 0.180 & & 0.179 & & 0.185 & & 0.274 & & 0.281 \\
\hline RMSE & & 1011.194 & & 1011.194 & & 011.623 & & 1008.233 & & 1062.524 & & 58.110 \\
\hline MAPE & & 32.175 & & 32.175 & & 32.084 & & 31.419 & & 189.786 & & 55.250 \\
\hline MaxAPE & & 743.186 & & 743.186 & & 739.979 & & 734.499 & & 2619.343 & & 80.665 \\
\hline MAE & & 624.809 & & 624.809 & & 625.503 & & 610.424 & & 643.019 & & 21.381 \\
\hline MaxMAE & & 4320.017 & & 4320.017 & & 1329.072 & & 4344.156 & & 5728.633 & & 92.211 \\
\hline Normalized BIC & & 13.965 & & 13.965 & & 13.966 & & 13.959 & & 14.065 & & 14.057 \\
\hline Ljung-Box & & 4.084 & & 4.084 & & 4.562 & & 5.021 & & 10.806 & & 9.536 \\
\hline
\end{tabular}

Tab. 2. Sesonally adjusted public investment in local elections Depended variable: Public Investments (PubInv)

\begin{tabular}{|c|c|c|c|c|c|c|c|c|c|c|c|c|}
\hline \multirow{2}{*}{$\begin{array}{l}\text { Model Type } \\
\qquad \operatorname{ARIMA}(0,0,1)\end{array}$} & \multicolumn{2}{|c|}{ Model 1} & \multicolumn{2}{|c|}{ Model 2} & \multicolumn{2}{|c|}{ Model 3} & \multicolumn{2}{|c|}{ Model 4} & \multicolumn{2}{|c|}{ Model 5} & \multicolumn{2}{|c|}{ Model 6} \\
\hline & Coeff. & Sig. & Coeff. & Sig. & Coeff. & Sig. & Coeff. & Sig. & Coeff. & Sig. & Coeff. & Sig. \\
\hline Constant & 2882.06 & 0.000 & 2790.23 & 0.000 & 2800.67 & 0.000 & 2746.63 & 0.000 & 2961.50 & 0.000 & 2962.57 & 0.000 \\
\hline Publnv (MA1) & -0.47 & 0.000 & -0.43 & 0.000 & -0.45 & 0.000 & -0.46 & 0.000 & -0.47 & 0.000 & -0.47 & 0.000 \\
\hline PD1 & 425.37 & 0.323 & & & & & & & & & & \\
\hline PD2 & & & 795.18 & 0.019 & & & & & & & & \\
\hline PD4 & & & & & & & 527.79 & 0.061 & & & & \\
\hline PD5 & & & & & & & & & -685.11 & 0.145 & & \\
\hline PD6 & & & & & & & & & & & -390.29 & 0.323 \\
\hline \multicolumn{13}{|c|}{ Diagnostic tests } \\
\hline Stationary R-squared & & 0.168 & & 0.202 & & 0.180 & & 0.188 & & 0.176 & & 0.167 \\
\hline RMSE & & 018.903 & & 997.839 & & 011.371 & & 006.545 & & 013.545 & & 1019.059 \\
\hline MAPE & & 33.694 & & 34.264 & & 33.939 & & 33.438 & & 33.726 & & 33.796 \\
\hline MaxAPE & & 812.662 & & 907.325 & & 832.898 & & 828.450 & & 761.654 & & 760.379 \\
\hline MAE & & 650.860 & & 646.389 & & 652.428 & & 643.206 & & 653.103 & & 656.529 \\
\hline MaxMAE & & 196.963 & & 3822.581 & & 010.004 & & 033.447 & & 1269.971 & & 4277.829 \\
\hline Normalized BIC & & 13.980 & & 13.938 & & 13.965 & & 13.956 & & 13.970 & & 13.981 \\
\hline Ljung-Box & & 5.416 & & 7.219 & & 5.092 & & 5.498 & & 5.886 & & 5.788 \\
\hline
\end{tabular}


Tab. 3. Seasonally adjusted compensation of employees in parliamentary elections Depended variable: Compensation of employees (ComEmp)

\begin{tabular}{|c|c|c|c|c|c|c|c|c|c|c|c|c|}
\hline \multirow{2}{*}{$\begin{array}{l}\text { Model Type } \\
\qquad \operatorname{ARIMA}(0,0,1)\end{array}$} & \multicolumn{2}{|c|}{ Model 1} & \multicolumn{2}{|c|}{ Model 2} & \multicolumn{2}{|c|}{ Model 3} & \multicolumn{2}{|c|}{ Model 4} & \multicolumn{2}{|c|}{ Model 5} & \multicolumn{2}{|c|}{ Model 6} \\
\hline & Coeff. & Sig. & Coeff. & Sig. & Coeff. & Sig. & Coeff. & Sig. & Coeff. & Sig. & Coeff. & Sig. \\
\hline Constant & 20.60 & 0.005 & 16.96 & 0.010 & 15.96 & 0.008 & 14.63 & 0.019 & 22.07 & 0.004 & 24.97 & 0.001 \\
\hline ComEmp (MA1) & 0.59 & 0.000 & 0.63 & 0.000 & 0.68 & 0.000 & 0.68 & 0.000 & 0.56 & 0.000 & 0.59 & 0.000 \\
\hline PD1 & 32.74 & 0.443 & & & & & & & & & & \\
\hline PD2 & & & 48.87 & 0.042 & & & & & & & & \\
\hline PD3 & & & & & 38.69 & 0.024 & & & & & & \\
\hline PD4 & & & & & & & 34.91 & 0.017 & & & & \\
\hline PD5 & & & & & & & & & 6.47 & 0.882 & & \\
\hline PD6 & & & & & & & & & & & -22.67 & 0.390 \\
\hline \multicolumn{13}{|c|}{ Diagnostic tests } \\
\hline Stationary R-squared & & 0.222 & & 0.243 & & 0.242 & & 0.246 & & 0.218 & & 0.223 \\
\hline R-squared & & 0.222 & & 0.243 & & 0.242 & & 0.246 & & 0.218 & & 0.223 \\
\hline RMSE & & 170.884 & & 168.559 & & 168.594 & & 168.202 & & 171.253 & & 0.732 \\
\hline MAPE & & 221.078 & & 212.370 & & 207.269 & & 192.236 & & 229.774 & & 29.785 \\
\hline MaxAPE & & 397.456 & & 161.794 & & 195.982 & & 860.938 & & 116.770 & & 4.876 \\
\hline MAE & & 120.559 & & 118.224 & & 118.895 & & 117.318 & & 121.221 & & 21.824 \\
\hline MaxMAE & & 738.425 & & 741.478 & & 739.071 & & 743.041 & & 738.666 & & 8.790 \\
\hline Normalized BIC & & 10.410 & & 10.383 & & 10.383 & & 10.379 & & 10.414 & & 0.408 \\
\hline Ljung-Box & & 15.742 & & 15.759 & & 18.898 & & 21.091 & & 16.406 & & 4.104 \\
\hline
\end{tabular}

Tab. 4. Seasonally adjusted compensation of employees in local elections Depended variable: Compensation of employees (ComEmp)

\begin{tabular}{|c|c|c|c|c|c|c|c|c|c|c|c|c|}
\hline \multirow{2}{*}{$\begin{array}{l}\text { Model Type } \\
\qquad \operatorname{ARIMA}(0,0,1)\end{array}$} & \multicolumn{2}{|c|}{ Model 1} & \multicolumn{2}{|c|}{ Model 2} & \multicolumn{2}{|c|}{ Model 3} & \multicolumn{2}{|c|}{ Model 4} & \multicolumn{2}{|c|}{ Model 5} & \multicolumn{2}{|c|}{ Model 6} \\
\hline & Coeff. & Sig. & Coeff. & Sig. & Coeff. & Sig. & Coeff. & Sig. & Coeff. & Sig. & Coeff. & Sig. \\
\hline Constant & 26.42 & 0.001 & 29.17 & 0.000 & 28.67 & 0.001 & 29.08 & 0.002 & 18.37 & 0.007 & 16.92 & 0.008 \\
\hline ComEmp (MA1) & 0.56 & 0.000 & 0.57 & 0.000 & 0.57 & 0.000 & 0.57 & 0.000 & 0.61 & 0.000 & 0.65 & 0.000 \\
\hline PD1 & -50.92 & 0.163 & & & & & & & & & & \\
\hline PD2 & & & -41.84 & 0.070 & & & & & & & & \\
\hline PD3 & & & & & -25.52 & 0.170 & & & & & & \\
\hline PD4 & & & & & & & -20.24 & 0.228 & & & & \\
\hline PD5 & & & & & & & & & 68.16 & 0.086 & & \\
\hline PD6 & & & & & & & & & & & 48.03 & 0.038 \\
\hline \multicolumn{13}{|c|}{ Diagnostic tests } \\
\hline Stationary R-squared & & 0.232 & & 0.242 & & 0.232 & & 0.229 & & 0.237 & & 0.242 \\
\hline R-squared & & 0.232 & & 0.242 & & 0.232 & & 0.229 & & 0.237 & & 0.242 \\
\hline RMSE & & 169.698 & & 168.630 & & 169.752 & & 170.083 & & 169.233 & & 68.694 \\
\hline MAPE & & 231.911 & & 222.062 & & 219.173 & & 220.094 & & 230.309 & & 18.295 \\
\hline MaxAPE & & 497.171 & & 105.332 & & 177.688 & & 2117.224 & & 769.639 & & 62.415 \\
\hline MAE & & 121.414 & & 119.995 & & 118.935 & & 119.029 & & 119.332 & & 17.452 \\
\hline MaxMAE & & 728.955 & & 722.187 & & 770.403 & & 767.119 & & 740.530 & & 39.646 \\
\hline Normalized BIC & & 10.396 & & 10.384 & & 10.397 & & 10.401 & & 10.391 & & 10.384 \\
\hline Ljung-Box & & 14.910 & & 14.659 & & 14.864 & & 16.294 & & 18.087 & & 21.208 \\
\hline
\end{tabular}


Tab. 5. Seasonally adjusted subsidies in parliamentary elections Depended variable: Subsidies (Sub)

\begin{tabular}{|c|c|c|c|c|c|c|c|c|c|c|c|c|}
\hline \multirow{2}{*}{$\begin{array}{l}\text { Model Type } \\
\text { ARIMA }(0,0,1)\end{array}$} & \multicolumn{2}{|r|}{ Model 1} & \multicolumn{2}{|r|}{ Model 2} & \multicolumn{2}{|r|}{ Model 3} & \multicolumn{2}{|r|}{ Model 4} & \multicolumn{2}{|r|}{ Model 5} & \multicolumn{2}{|c|}{ Model 6} \\
\hline & Coeff. & Sig. & Coeff. & Sig. & Coeff. & Sig. & Coeff. & Sig. & Coeff. & Sig. & Coeff. & Sig. \\
\hline Constant & 1.64 & 0.844 & 0.87 & 0.921 & -2.98 & 0.738 & -6.08 & 0.506 & -0.12 & 0.988 & -2.41 & 0.784 \\
\hline Sub (MA1) & 0.91 & 0.000 & 0.91 & 0.000 & 0.92 & 0.000 & 0.92 & 0.000 & 0.91 & 0.000 & 0.91 & 0.000 \\
\hline PD1 & -10.57 & 0.908 & & & & & & & & & & \\
\hline PD2 & & & 0.89 & 0.986 & & & & & & & & \\
\hline PD3 & & & & & 20.79 & 0.567 & & & & & & \\
\hline PD4 & & & & & & & 27.56 & 0.342 & & & & \\
\hline PD5 & & & & & & & & & 18.32 & 0.838 & & \\
\hline PD6 & & & & & & & & & & & 28.59 & 0.559 \\
\hline \multicolumn{13}{|c|}{ Diagnostic tests } \\
\hline Stationary R-squared & & 0.450 & & 0.450 & & 0.452 & & 0.455 & & 0.450 & & 0.452 \\
\hline R-squared & & 0.450 & & 0.450 & & 0.452 & & 0.455 & & 0.450 & & 0.452 \\
\hline RMSE & & 658.448 & & 658.471 & & 657.282 & & 655.415 & & 658.384 & & 7.726 \\
\hline MAPE & & 410.387 & & 407.741 & & 392.121 & & 381.478 & & 410.295 & & 1.664 \\
\hline MaxAPE & & 447.361 & & | 453.283 & & 257.463 & & 954.201 & & 1611.427 & 1218 & 3.398 \\
\hline MAE & & 248.217 & & 248.797 & & 249.689 & & 251.186 & & 250.191 & & 4.619 \\
\hline MaxMAE & & 869.259 & & 5860.961 & & 839.604 & & 5835.520 & & 5838.311 & 576 & 7.117 \\
\hline Normalized BIC & & 13.108 & & 13.108 & & 13.104 & & 13.099 & & 13.108 & & 3.106 \\
\hline Ljung-Box & & 16.729 & & 16.882 & & 17.092 & & 17.015 & & 16.889 & & 6.701 \\
\hline
\end{tabular}

Tab. 6. Seasonally adjusted subsidies in local elections Depended variable: Subsidies (Sub)

\begin{tabular}{|c|c|c|c|c|c|c|c|c|c|c|c|c|}
\hline \multirow{2}{*}{$\begin{array}{l}\text { Model Type } \\
\operatorname{ARIMA}(0,0,1)\end{array}$} & \multirow[b]{2}{*}{ Coeff. } & \multicolumn{2}{|l|}{ Model 1} & Model 2 & \multicolumn{2}{|r|}{ Model 3} & \multicolumn{2}{|r|}{ Model 4} & \multicolumn{2}{|r|}{ Model 5} & \multicolumn{2}{|c|}{ Model 6} \\
\hline & & Sig. & Coeff. & Sig. & Coeff. & Sig. & Coeff. & Sig. & Coeff. & Sig. & Coeff. & Sig. \\
\hline Constant & -7.96 & 0.329 & -7.45 & 0.403 & -6.81 & 0.489 & -5.18 & 0.639 & -7.99 & 0.330 & -5.29 & 0.545 \\
\hline Sub (MA1) & 0.92 & 0.000 & 0.92 & 0.000 & 0.92 & 0.000 & 0.92 & 0.000 & 0.92 & 0.000 & 0.92 & 0.000 \\
\hline PD1 & 121.70 & 0.141 & & & & & & & & & & \\
\hline PD2 & & & 55.45 & 0.225 & & & & & & & & \\
\hline PD3 & & & & & 33.24 & 0.331 & & & & & & \\
\hline PD4 & & & & & & & 19.33 & 0.508 & & & & \\
\hline PD5 & & & & & & & & & 134.59 & 0.130 & & \\
\hline PD6 & & & & & & & & & & & 47.42 & 0.337 \\
\hline \multicolumn{13}{|c|}{ Diagnostic tests } \\
\hline Stationary R-squared & & 0.462 & & 0.458 & & 0.456 & & 0.453 & & 0.462 & & 0.455 \\
\hline R-squared & & 0.462 & & 0.458 & & 0.456 & & 0.453 & & 0.462 & & 0.455 \\
\hline RMSE & & 651.650 & & 653.707 & & 655.306 & & 656.923 & & 651.251 & & 5.455 \\
\hline MAPE & & 333.966 & & 341.957 & & 345.060 & & 341.946 & & 359.509 & & 4.385 \\
\hline MaxAPE & & 234.480 & & 200.623 & & 254.131 & & 501.744 & & 728.870 & 1107 & 4.962 \\
\hline MAE & & 242.527 & & 244.600 & & 246.649 & & 245.475 & & 245.852 & & 6.783 \\
\hline MaxMAE & & 891.344 & & 5901.313 & & 5905.863 & & 5900.661 & & 5851.593 & 584 & 12.030 \\
\hline Normalized BIC & & 13.087 & & 13.094 & & 13.098 & & 13.103 & & 13.086 & & 3.099 \\
\hline Ljung-Box & & 17.221 & & 18.549 & & 18.032 & & 16.997 & & 16.392 & & 17.566 \\
\hline
\end{tabular}


Tab. 7. Seasonally adjusted unemployment insurance benefits in parlia- empInsBen) mentary elections Depended variable: Unemployment insurance benefits (Un-

\begin{tabular}{|c|c|c|c|c|c|c|c|c|c|c|c|c|}
\hline \multirow{2}{*}{$\begin{array}{l}\text { Model Type } \\
\operatorname{ARIMA}(0,0,1)\end{array}$} & \multicolumn{3}{|c|}{ Model 1} & \multicolumn{2}{|l|}{ Model 2} & \multicolumn{2}{|l|}{ Model 3} & \multicolumn{2}{|l|}{ Model 4} & Model 5 & \multicolumn{2}{|r|}{ Model 6} \\
\hline & Coeff. & Sig. & Coeff. & Sig. & Coeff. & Sig. & Coeff. & Sig. & Coeff. & Sig. & Coeff. & Sig. \\
\hline Constant & -0.20 & 0.820 & -0.20 & 0.833 & -0.73 & 0.460 & -0.98 & 0.337 & -0.07 & 0.929 & 0.18 & 0.827 \\
\hline UnemplnsBen (MA1) & 0.77 & 0.000 & 0.76 & 0.000 & 0.76 & 0.000 & 0.76 & 0.000 & 0.78 & 0.000 & 0.79 & 0.000 \\
\hline PD1 & -7.51 & 0.256 & & & & & & & & & & \\
\hline PD2 & & & -3.82 & 0.350 & & & & & & & & \\
\hline PD3 & & & & & 0.49 & 0.871 & & & & & & \\
\hline PD4 & & & & & & & 1.47 & 0.567 & & & & \\
\hline PD5 & & & & & & & & & -9.57 & 0.130 & & \\
\hline PD6 & & & & & & & & & & & -6.91 & 0.051 \\
\hline \multicolumn{13}{|c|}{ Diagnostic tests } \\
\hline Stationary R-squared & & 0.464 & & 0.462 & & 0.457 & & 0.459 & & 0.468 & & 0.474 \\
\hline R-squared & & 0.464 & & 0.462 & & 0.457 & & 0.459 & & 0.468 & & 0.474 \\
\hline RMSE & & 34.909 & & 34.959 & & 35.121 & & 35.066 & & 34.777 & & 34.563 \\
\hline MAPE & & 114.669 & & 111.296 & & 109.510 & & 109.423 & & 119.922 & & 117.994 \\
\hline MaxAPE & & 682.828 & & 505.926 & & 608.384 & & 809.501 & & 1307.607 & & 931.880 \\
\hline MAE & & 21.881 & & 21.913 & & 21.976 & & 22.032 & & 21.919 & & 21.826 \\
\hline MaxMAE & & 194.748 & & 194.508 & & 195.515 & & 192.789 & & 194.688 & & 193.794 \\
\hline Normalized BIC & & 7.234 & & 7.237 & & 7.246 & & 7.243 & & 7.226 & & 7.214 \\
\hline Ljung-Box & & 19.625 & & 19.310 & & 20.062 & & 20.489 & & 19.365 & & 19.772 \\
\hline
\end{tabular}

Tab. 8. Seasonally adjusted unemployment insurance benefits in local elections. Depended variable: Unemployment insurance benefits (UnempInsBen)

\begin{tabular}{|c|c|c|c|c|c|c|c|c|c|c|c|c|}
\hline \multirow{2}{*}{$\begin{array}{l}\text { Model Type } \\
\operatorname{ARIMA}(0,0,1)\end{array}$} & \multicolumn{3}{|c|}{ Model 1} & \multirow{2}{*}{$\begin{array}{c}\text { Model } 2 \\
\text { Sig. }\end{array}$} & \multicolumn{3}{|c|}{ Model 3} & Model 4 & \multicolumn{2}{|r|}{ Model 5} & \multicolumn{2}{|c|}{ Model 6} \\
\hline & Coeff. & Sig. & Coeff. & & Coeff. & Sig. & Coeff. & Sig. & Coeff. & Sig. & Coeff. & Sig. \\
\hline Constant & -1.38 & 0.093 & -1.61 & 0.057 & -1.58 & 0.080 & -2.14 & 0.023 & -1.68 & 0.050 & -1.19 & 0.199 \\
\hline UnemplnsBen (MA1) & 0.79 & 0.000 & 0.80 & 0.000 & 0.80 & 0.000 & 0.80 & 0.000 & 0.77 & 0.000 & 0.77 & 0.000 \\
\hline PD1 & 10.29 & 0.063 & & & & & & & & & & \\
\hline PD2 & & & 6.43 & 0.039 & & & & & & & & \\
\hline PD3 & & & & & 4.04 & 0.090 & & & & & & \\
\hline PD4 & & & & & & & 4.69 & 0.019 & & & & \\
\hline PD5 & & & & & & & & & 17.33 & 0.007 & & \\
\hline PD6 & & & & & & & & & & & 4.67 & 0.241 \\
\hline \multicolumn{13}{|c|}{ Diagnostic tests } \\
\hline Stationary R-squared & & 0.473 & & 0.476 & & 0.469 & & 0.481 & & 0.493 & & 0.464 \\
\hline R-squared & & 0.473 & & 0.476 & & 0.469 & & 0.481 & & 0.493 & & 0.464 \\
\hline RMSE & & 34.595 & & 34.490 & & 34.719 & & 34.323 & & 33.931 & & 34.891 \\
\hline MAPE & & 103.021 & & 98.080 & & 103.175 & & 108.774 & & 112.310 & & 112.254 \\
\hline MaxAPE & & 761.651 & & 698.271 & & 545.789 & & 668.750 & & 726.958 & & 313.854 \\
\hline MAE & & 21.364 & & 20.932 & & 21.320 & & 21.323 & & 22.170 & & 22.167 \\
\hline MaxMAE & & 188.883 & & 190.821 & & 193.841 & & 194.466 & & 160.302 & & 188.011 \\
\hline Normalized BIC & & 7.216 & & 7.210 & & 7.223 & & 7.200 & & 7.177 & & 7.233 \\
\hline Ljung-Box & & 19.342 & & 16.634 & & 16.613 & & 16.708 & & 20.985 & & 20.455 \\
\hline
\end{tabular}


Tab. 9. Seasonally adjusted social assistance in parliamentary elections Depended variable: Social assistance (SocAss)

\begin{tabular}{|c|c|c|c|c|c|c|c|c|c|c|c|c|}
\hline \multirow{2}{*}{$\begin{array}{l}\text { Model Type } \\
\operatorname{ARIMA}(0,0,1)\end{array}$} & \multicolumn{3}{|c|}{ Model 1} & Model 2 & \multicolumn{2}{|r|}{ Model 3} & \multicolumn{2}{|r|}{ Model 4} & \multicolumn{2}{|r|}{ Model 5} & \multicolumn{2}{|c|}{ Model 6} \\
\hline & Coeff. & Sig. & Coeff. & Sig. & Coeff. & Sig. & Coeff. & Sig. & Coeff. & Sig. & Coeff. & Sig. \\
\hline Constant & 10.02 & 0.037 & 11.41 & 0.028 & 10.57 & 0.051 & 10.03 & 0.078 & 9.43 & 0.059 & 9.32 & 0.079 \\
\hline SocAss (MA1) & 0.84 & 0.000 & 0.84 & 0.000 & 0.84 & 0.000 & 0.83 & 0.000 & 0.83 & 0.000 & 0.82 & 0.000 \\
\hline PD1 & -51.76 & 0.202 & & & & & & & & & & \\
\hline PD2 & & & -36.98 & 0.115 & & & & & & & & \\
\hline PD3 & & & & & -19.99 & 0.255 & & & & & & \\
\hline PD4 & & & & & & & -12.59 & 0.395 & & & & \\
\hline PD5 & & & & & & & & & -40.20 & 0.336 & & \\
\hline PD6 & & & & & & & & & & & -18.65 & 0.437 \\
\hline \multicolumn{13}{|c|}{ Diagnostic tests } \\
\hline Stationary R-squared & & 0.345 & & 0.351 & & 0.344 & & 0.340 & & 0.341 & & 0.339 \\
\hline R-squared & & 0.345 & & 0.351 & & 0.344 & & 0.340 & & 0.341 & & 0.339 \\
\hline RMSE & & 252.984 & & 251.850 & & 253.287 & & 254.009 & & 253.812 & & 4.229 \\
\hline MAPE & & 304.409 & & 278.415 & & 288.993 & & 291.566 & & 336.733 & & 9.947 \\
\hline MaxAPE & & 7046.533 & & 3275.795 & & 3802.239 & & 5844.412 & & 1845.285 & 1177 & 8.249 \\
\hline MAE & & 112.620 & & 112.729 & & 112.536 & & 113.361 & & 114.182 & & 5.024 \\
\hline MaxMAE & & 1597.225 & & 1590.206 & & 1593.125 & & 1595.790 & & 1603.853 & 160 & 6.788 \\
\hline Normalized BIC & & 11.195 & & 11.186 & & 11.197 & & 11.203 & & 11.201 & & 1.205 \\
\hline Ljung-Box & & 5.277 & & 4.939 & & 5.269 & & 5.552 & & 4.646 & & 4.633 \\
\hline
\end{tabular}

Tab. 10. Seasonally adjusted social assistance in local elections Depended variable: Social assistance (SocAss)

\begin{tabular}{|c|c|c|c|c|c|c|c|c|c|c|c|c|}
\hline \multirow{2}{*}{$\begin{array}{l}\text { Model Type } \\
\operatorname{ARIMA}(0,0,1)\end{array}$} & \multicolumn{3}{|c|}{ Model 1} & Model 2 & \multicolumn{2}{|r|}{ Model 3} & \multicolumn{2}{|r|}{ Model 4} & \multicolumn{2}{|r|}{ Model 5} & \multicolumn{2}{|c|}{ Model 6} \\
\hline & Coeff. & Sig. & Coeff. & Sig. & Coeff. & Sig. & Coeff. & Sig. & Coeff. & Sig. & Coeff. & Sig. \\
\hline Constant & 3.78 & 0.450 & 0.67 & 0.889 & -0.52 & 0.914 & -1.08 & 0.833 & -0.83 & 0.887 & 0.22 & 0.974 \\
\hline SocAss (MA1) & 0.84 & 0.000 & 0.86 & 0.000 & 0.87 & 0.000 & 0.87 & 0.000 & 0.86 & 0.000 & 0.85 & 0.000 \\
\hline PD1 & 43.35 & 0.251 & & & & & & & & & & \\
\hline PD2 & & & 40.17 & 0.042 & & & & & & & & \\
\hline PD3 & & & & & 30.43 & 0.035 & & & & & & \\
\hline PD4 & & & & & & & 23.99 & 0.053 & & & & \\
\hline PD5 & & & & & & & & & 18.43 & 0.115 & & \\
\hline PD6 & & & & & & & & & & & 13.36 & 0.258 \\
\hline \multicolumn{13}{|c|}{ Diagnostic tests } \\
\hline Stationary R-squared & & 0.344 & & 0.360 & & 0.362 & & 0.358 & & 0.351 & & 0.344 \\
\hline R-squared & & 0.344 & & 0.360 & & 0.362 & & 0.358 & & 0.351 & & 0.344 \\
\hline RMSE & & 253.233 & & 250.070 & & 249.762 & & 250.451 & & 251.864 & & 3.297 \\
\hline MAPE & & 350.936 & & 393.335 & & 389.512 & & 399.201 & & 386.661 & & 8.791 \\
\hline MaxAPE & & 3683.537 & & 6625.583 & & 5477.843 & & 4899.816 & & 5136.744 & 612 & 0.628 \\
\hline MAE & & 118.469 & & 122.844 & & 124.107 & & 123.185 & & 121.461 & & 9.810 \\
\hline MaxMAE & & 1587.184 & & 1522.038 & & 1516.687 & & 1528.138 & & 1548.870 & 157 & 1.802 \\
\hline Normalized BIC & & 11.197 & & 11.172 & & 11.169 & & 11.175 & & 11.186 & & 1.197 \\
\hline Ljung-Box & & 5.471 & & 5.668 & & 5.812 & & 5.653 & & 5.743 & & 6.069 \\
\hline
\end{tabular}


Tab. 11. Seasonally adjusted deficit in parliamentary elections Depended variable: Deficit (Def)

\begin{tabular}{|c|c|c|c|c|c|c|c|c|c|c|c|c|}
\hline \multirow{2}{*}{$\begin{array}{l}\text { Model Type } \\
\operatorname{ARIMA}(0,0,1)\end{array}$} & \multicolumn{3}{|c|}{ Model 1} & Model 2 & \multicolumn{2}{|r|}{ Model 3} & \multicolumn{2}{|r|}{ Model 4} & \multicolumn{2}{|r|}{ Model 5} & \multicolumn{2}{|c|}{ Model 6} \\
\hline & Coeff. & Sig. & Coeff. & Sig. & Coeff. & Sig. & Coeff. & Sig. & Coeff. & Sig. & Coeff. & Sig. \\
\hline Constant & 10.89 & 0.536 & 11.06 & 0.561 & 12.77 & 0.538 & 14.92 & 0.509 & -11.71 & 0.480 & -8.61 & 0.616 \\
\hline Def (MA1) & 1.00 & 0.000 & 1.00 & 0.016 & 1.00 & 0.000 & 1.00 & 0.002 & 0.99 & 0.000 & 1.00 & 0.102 \\
\hline PD1 & 231.52 & 0.367 & & & & & & & & & & \\
\hline PD2 & & & 115.72 & 0.404 & & & & & & & & \\
\hline PD3 & & & & & 67.39 & 0.503 & & & & & & \\
\hline PD4 & & & & & & & 42.77 & 0.604 & & & & \\
\hline PD5 & & & & & & & & & 596.03 & 0.018 & & \\
\hline PD6 & & & & & & & & & & & 284.68 & 0.037 \\
\hline \multicolumn{13}{|c|}{ Diagnostic tests } \\
\hline Stationary R-squared & & 0.369 & & 0.369 & & 0.367 & & 0.366 & & 0.392 & & 0.387 \\
\hline R-squared & & 0.369 & & 0.369 & & 0.367 & & 0.366 & & 0.392 & & 0.387 \\
\hline RMSE & & 138.887 & & 2139.546 & & 142.379 & & 2144.486 & & 100.067 & 210 & 8.483 \\
\hline MAPE & & 263.108 & & 266.828 & & 276.288 & & 284.737 & & 243.311 & & 18.359 \\
\hline MaxAPE & & 476.985 & & 8511.058 & & 3646.437 & & 8731.619 & & 177.457 & 767 & 71.338 \\
\hline MAE & & 243.243 & & 1246.108 & & 257.810 & & 1266.439 & & 193.878 & 120 & 00.716 \\
\hline MaxMAE & & 739.094 & & 4724.793 & & 700.630 & & 4693.593 & & 931.468 & 1503 & 37.951 \\
\hline Normalized BIC & & 15.464 & & 15.465 & & 15.468 & & 15.470 & & 15.428 & & 15.436 \\
\hline Ljung-Box & & 18.195 & & 18.854 & & 19.351 & & 19.522 & & 13.670 & & 14.436 \\
\hline
\end{tabular}

Tab. 12. Seasonally adjusted deficit in local elections Depended variable: Deficit (Def)

\begin{tabular}{|c|c|c|c|c|c|c|c|c|c|c|c|c|}
\hline \multirow{2}{*}{$\begin{array}{l}\text { Model Type } \\
\operatorname{ARIMA}(0,0,1)\end{array}$} & \multicolumn{3}{|c|}{ Model 1} & \multirow{2}{*}{$\begin{array}{c}\text { Model } 2 \\
\text { Sig. }\end{array}$} & \multicolumn{3}{|c|}{ Model 3} & Model 4 & \multicolumn{2}{|r|}{ Model 5} & \multicolumn{2}{|c|}{ Model 6} \\
\hline & Coeff. & Sig. & Coeff. & & Coeff. & Sig. & Coeff. & Sig. & Coeff. & Sig. & Coeff. & Sig. \\
\hline Constant & 29.93 & 0.175 & 57.96 & 0.015 & 64.27 & 0.011 & 65.22 & 0.018 & 63.04 & 0.015 & 60.57 & 0.019 \\
\hline Def (MA1) & 0.99 & 0.000 & 1.00 & 0.001 & 1.00 & 0.474 & 1.00 & 0.068 & 1.00 & 0.058 & 1.00 & 0.078 \\
\hline PD1 & -52.27 & 0.847 & & & & & & & & & & \\
\hline PD2 & & & -208.17 & 0.145 & & & & & & & & \\
\hline PD3 & & & & & -163.55 & 0.107 & & & & & & \\
\hline PD4 & & & & & & & -124.34 & 0.137 & & & & \\
\hline PD5 & & & & & & & & & 137.98 & 0.608 & & \\
\hline PD6 & & & & & & & & & & & 28.23 & 0.845 \\
\hline \multicolumn{13}{|c|}{ Diagnostic tests } \\
\hline Stationary R-squared & & 0.362 & & 0.374 & & 0.378 & & 0.378 & & 0.374 & & 0.378 \\
\hline R-squared & & 0.362 & & 0.374 & & 0.378 & & 0.378 & & 0.374 & & 0.378 \\
\hline RMSE & & 149.965 & & 2130.502 & & 122.970 & & 123.855 & & 130.502 & & 23.855 \\
\hline MAPE & & 307.241 & & 317.547 & & 307.237 & & 289.490 & & 317.547 & & 39.490 \\
\hline MaxAPE & & 499.018 & & 1776.050 & & 230.035 & & 345.742 & & 776.050 & 93 & 45.742 \\
\hline MAE & & 273.976 & & 1263.646 & & 264.404 & & 1269.125 & & 263.646 & 12 & 69.125 \\
\hline MaxMAE & & 751.456 & & 4517.136 & & 407.747 & & 4405.792 & & 517.136 & 144 & 05.792 \\
\hline Normalized BIC & & 15.475 & & 15.456 & & 15.449 & & 15.450 & & 15.456 & & 15.450 \\
\hline Ljung-Box & & 18.666 & & 16.717 & & 16.568 & & 16.611 & & 16.717 & & 16.611 \\
\hline
\end{tabular}

